\title{
Managers' Perceptions of Regulatory Legislation of Private Higher Education in South Africa
}

\author{
M.E. Ellis ${ }^{1}$ and G.M. Steyn ${ }^{2}$ \\ ${ }^{1}$ Master's student Department of Educational Leadership and Management, \\ University of South Africa, PO Box 392, Pretoria 0003, South Africa \\ Telephone: +27 861007225; Mobile: +27 825789104 \\ E-mail: ${ }^{1<m a r e l i z e @ a k a d e m i a . a c . z a>~}$ \\ ${ }^{2}$ Department of Educational Leadership and Management, University of South Africa, \\ PO Box 392, Pretoria 0003, South Africa \\ Telephone: +27 82886 7468; Fax: +27 86642 1645, \\ E-mail: ${ }^{2}<$ steyngm1@unisa.ac.za>
}

\begin{abstract}
KEYWORDS Higher Education Policies. Transformation of Higher Education. Regulatory Framework. Control. Management

ABSTRACT Higher education in general is regulated through government regulations and policies. This paper reports on part of an investigation done for a master's dissertation. The broad research aim of the study was to provide research-based documented evidence of the impact of the higher education regulatory context on the management of a private higher education institution in South Africa. This paper is limited to the findings of the study, though it focused on how the management team of a private higher education institution perceived the impact of regulatory legislation on private higher education. To study the phenomenon, a qualitative research methodology was used and data were collected through interviews with management team members. Official documents on higher education legislation also served as data sources. A case study using an accredited and registered private higher education institution was undertaken.
\end{abstract}

\section{INTRODUCTION}

The privatisation of higher education institutions has been one of the key changes in the higher education sector nationally and internationally in recent years (Baine 2010; Wang 2010). Private higher educational institutions are predominantly being run as businesses and, like other organisations, they are linked to and influenced by factors such as national and global economic, social and political developments (Baine 2010; Wang 2010; Vidovich and Currie 2011). The pre-1994 higher education system in South Africa was also shaped by class, race, gender, and institutional and spatial inequalities. South Africa's first democratic government led by the African National Congress committed itself to transforming higher education, addressing the inherited apartheid social structure and institutionalising a new social order (Badat 2007; Kruger 2010; Van der Bank and Basson 2014). As a result, higher education in South Africa has been subject to rigid regulatory state intervention in order to introduce market-based competition, social equity and institutional capacity-building according to international best practice and standards (King 2006).
Higher education plays an important role in preparing a nation to become "globally and economically competitive in a fast-developing knowledge-based world” (King 2006; Department of Education and Skills 2011; Nachef et al. 2014). To ensure quality and for the sake of public interest, higher education is strictly regulated in many advanced societies (Moran 2002; King 2006; Dubash and Morgan 2011). In line with international developments, the notion of the higher education regulatory state for the sake of quality assurance has also developed in the South African higher education sector.

For a number of reasons, the government and the public sector in South Africa were alarmed by the remarkable growth of the private higher education institutions. One of the reasons was that private higher education providers would attract students from public higher education institutions. In addition the government and public sector questioned the quality of facilities, staff, resources and value for money offered by private institutions (MacGregor 2008). Government also thought that the unrestrained expansion of private higher education institutions and public-private partnerships would disrupt national planning and coordination. Owing 
to the rapid expansion of private higher education in the higher education sphere, government's legislative developments focused on private higher education institutions (Subotzky 2003).

The transformation of higher education led to tension between equity and efficiency in the system. This tension resulted inter alia in the development of legislation for higher education (Gravett and Geyser 2004; Cloete 2014). Recent policies and legislation increased the power of the Minister of Education, which is an indication of the continuation of strong top-down regulation which is centrally driven and strongly interventionist (King 2006).

\section{Objective of the Study}

Limited research has been conducted into the current regulatory context of private higher education institutions in South Africa. No studies have been conducted to determine the impact of the regulatory context on the management of a private higher education institution in South Africa. This paper reports on part of an investigation done for a master's dissertation (Ellis 2012). The broad research aim of the Master's study was to determine the impact of the higher education regulatory context on the management of a private higher education institution in South Africa. This paper is limited to the findings of the study, although limited to the findings of the Master's study, the purpose of this study was to assess how the management team of a private higher education institution perceived the regulatory higher education policies and acts of South Africa. It focused on the perceptions and experiences of a management team within the higher education regulatory context in South Africa.

\section{A Brief History of the Higher Education Regulatory Context in South Africa}

Government policies and regulations governing higher education in South Africa attempt to redress the institutional inequalities and racial differentiation that characterised higher education during the apartheid era. In addition they attempt to develop the overall capacities of higher education institutions so that South Africa may compete successfully in the global economy (King 2006). One characteristic of the centra- lised government approach to regulation in higher education in South Africa is the emphasis of a 'top-down' model (King 2006).

The policy framework and the goals, values and principles as outlined in the Education White Paper 3 - A Programme for Higher Education Transformation (Department of Education 1997a) formed the basis of the National Plan for Higher Education (Department of Education 2001). Government used the principles in the White Paper (Department of Education 1997a) as a basis to stay abreast of new trends in higher education across the globe. Included were regional cooperation concerning language policies, the development of a new funding policy, a regulatory framework for quality assurance and proposals for the restructuring of the higher education landscape through mergers and incorporations. King (2006) believes that the implementation initiatives has given rise to capacity problems, and these problems have been compounded by continual regulatory and policy initiatives that have not always been adequately linked to the National Plan for Higher Education.

An institution may only provide higher education if it can prove that it is registered with the Department of Education, that its programmes have been registered on the National Qualifications Framework by the South African Qualifications Authority and that it fulfils the higher education quality assurance function through institutional and programme accreditation (Council on Higher Education 2003; Department of Education 2004; Department of Education 2008). An institution can only be registered if it can provide proof that it has the capacity to fulfil its financial obligations to prospective students and complies with the criteria of the Higher Education Quality Committee (Department of Education 1997b; Department of Education 2008; Department of Education 2002:64-65). The Higher Education Act (Department of Education 1997b) stipulates that an institution must register and trade as a juristic person or an external company in terms of the Companies Act 61 of 1973 (Department of Trade and Industry 1973). It must also comply with the health and safety regulations of the Department of Labour, and be subjected to periodical evaluations by the Department of Education (Department of Education 2002; Department of Education 2008). 
Management aims to improve the quality of the learning environment by leading, by managing the education process, and by allocating and controlling resources in a way that improves the quality of the learning environment (Daigneau 2005). Human resource management is subject to the guidance of the Department of Labour as well as the Department of Education (Council on Higher Education 2004; Department of Labour 1997). The Department of Labour's regulatory framework requires management to promote the development of staff members' skills by providing training and development opportunities as listed in its Workplace Skills Plan and Workplace Skills Report (WSR) (Gravett and Geyser 2004). In addition, the Higher Education Quality Committee requires clear policies, procedures and strategies for full-time and part-time staff pertaining to recruitment, selection and appointments. These policies, procedures and strategies should comply with the stipulations of the Department of Labour's regulatory framework. Along these lines, the selection procedure indicates, among other things, that academic staff members, such as lecturers and internal and external moderators, should meet the redress and equity requirements of the Department of Labour and the management profiles of the institution.

Physical resources, such as teaching and learning venues, buildings and libraries, play an important role in teaching and learning, and are financial assets and financial resources. Thus, the institution is bound by the regulations of the Department of Labour (health and safety), the Department of Trade and Industry (financial resources) and the Department of Education (teaching and learning) (Department of Education 2002). These regulations emphasise the importance of the teaching and learning experience in terms of sufficient space, equipment and instructional material to provide education and training to achieve the objectives of the programmes.

The Council on Higher Education's information gathering processes take the form of prescribed quality assurance evidence reports pertaining to the different submission processes of the Council on Higher Education. The outcomes of both the programme accreditation and institutional audit processes are placed in the public domain to inform the public about the state of quality arrangements in the institutions. Being registered and accredited means that the insti- tution provides viable high-quality products and services in the business of teaching and learning in higher education (Council on Higher Education 2006a).

The regulatory framework deprives private higher education institutions in South Africa of the following: their institutional autonomy; academic freedom; self-regulation and administrative independence with respect to student admissions; curriculum; methods of teaching and assessment; research; establishment of academic regulations and the internal management of resources generated from private and public sources, even though these are fundamental rights protected by the Constitution (Department of Education 1997a). However, the government's view is that it needs to intervene to ensure that higher education institutions are not involved in illegal activities, and that they meet the demands of democratic change and government's expectations, especially if they receive public funding (Pandor 2004; Council on Higher Education 2006b).

Although private higher education providers offer more career-focused and short-cycle certificates and diploma programmes, the Minister of Education and the Council on Higher Education agree that the higher education sector was inadequately regulated in the past, because they were not required to fulfil a complementary role to public higher education institutions and/or contributing to social development. Therefore, the post-1994 regulatory framework focused primarily on private higher education institutions through the Higher Education (HE) Act (Department of Education 1997b), its amendments and the regulations for the registration of private higher education institutions (Department of Education 2002). The regulatory framework ensured that private higher education institutions would be financially viable and would have the necessary physical and human capacity. In addition it ensured that their academic offerings meet acceptable standards of quality (Council on Higher Education 2003). However, the highly prescriptive regulation of private higher education since 2001 has led to a huge decline in the number of international private higher education providers operating in South Africa (King 2006).

Since the introduction of the regulatory framework in 1998 private higher education in- 
stitutions have been engaged in the complex dual process of registering with the Department of Education and seeking accreditation with the South African Qualifications Authority. The Council for Higher Education took over the programme accreditation function from South African Qualifications Authority and introduced new accreditation criteria and procedures (Council on Higher Education 2003). The Council on Higher Education also began to implement its other functions (such as the auditing of institutions and the promotion of quality assurance at higher education level), as laid down by the Higher Education Act. All these components of the regulatory framework had a disruptive impact on private higher education institutions and its management.

Accreditation of programmes offered at higher education institutions is a continuous process and the Council of Higher Education requires the accreditation of all new programmes and the reaccreditation of programmes once a programme cycle has expired. Both accreditation and re-accreditation focus on the level and aim of programmes, the infrastructure present in the institution and whether academic staff are adequately qualified to teach the programme.

\section{Conceptual Framework}

Laszlo and Krippner (1998) stated that a systems inquiry presents a rich collection of conceptual tools for studying perceptions. Considering the research problem, this inquiry was appropriate and enabled the researchers to understand management's perceptions of the regulatory environment in private higher education in South Africa. It means that the systems theory provides insights into the way in which organisations function within their environment (Asimiran 2009; Bush 2011). The systems theory emphasises the unity of organisations and focuses on the interaction between their components and the external environment (Bush 2011; Stacey et al. 2000). Therefore, according to the systems theory, the "interrelatedness" of an institution and its external environment needs to be acknowledged (Smit et al. 2007; Laszlo and Krippner 1998). This implies that the institution as a system does not operate in isolation, but depends on the environment in which it functions (Asimiran 2009; Smit et al. 2007). Similarly, higher educational institutions form part of the environment in which they operate and are strongly influenced by government and the society (Laszlo and Krippner 1998; Asimiran 2009). The systems model nevertheless emphasises the notion of a system boundary which distinguishes the organisation from its external environment (Bush 2011).

The systems theory distinguishes between open and closed systems in terms of an institution's relationship with its environment (Bush 2011). Closed systems take little account of the external environment, whereas open systems acknowledge the relationship between the institution and external groups, in this case the Department of Education, prospective students and the public and other private service providers. Open systems assume "permeable boundaries and the interactive two-way relationships" between institutions and their environment (Bush 2011). Private higher education providers may therefore be regarded as open systems that constantly need to interact with, among others, officials in the regulatory environment, while they also need to achieve institutional objectives to maintain their credibility and viability.

In the context of the regulatory environment in higher education in South Africa, interdependent parts include the various policies designed by the Department of Education as a strategic plan for quality assurance, ensuring global competiveness and the redress of social inequality. As a result these different interdependent parts create linkages within the private higher education system. Therefore, considering the various legislative and policy initiatives in the higher education environment in South Africa, the systems theory plays an important role in understanding the perceptions of management in higher education institutions.

\section{RESEARCH METHODOLOGY}

Since the objective of this study was to gain an in-depth understanding of the experiences of the management of a private higher education institution regarding the regulatory environment in South Africa, a qualitative research design, in particular a case study, was employed (Cohen et al. 2007; Creswell 2007). A private higher education institution that offered a variety of programmes on different levels was purposefully selected. The data were collected by means of individual interviews with the six staff members at management level; they participated in the 
management process and were involved in the accreditation of their institution. The management team included the Chief Executive Officer; the Academic Director; the Registrar; the Head: Student Recruitment; the Head: Examinations and Administration; and the Head: Finance. The interviews were held on times and dates that suited for each participant (Wholey et al. 2004).

This study was located within the regulatory policy framework of higher education and it focused on the perceptions and experiences of managerial staff with regard to the requirements of stipulated policies. Open-ended, specific semistructured questions were used and a general question opened the interview: How do you experience the current higher education regulatory framework in your institution? Permission was granted by the participants to take field notes and to record the interviews electronically (Warren 2002). All field notes were expanded after the interviews and the recorded interviews were transcribed (Adam 2003). The data also included official documents, such as Acts and policies pertaining to private higher education.

This study followed an interpretative approach, which assisted the researchers in the gaining firsthand information about the managers' subjective views, experiences and feelings (Livesey 2006; Nieuwenhuis 2010) regarding the regulatory environment in South Africa. This was done by focusing on the experiences and perceptions of managers of a private higher education institution following the implementation of private higher education legislation (Visagie 2002; Giles 2007).

The data analysis process started during the individual interviews as the discussions facilitated the generation of rich data, which were complemented by field notes and transcribed information (Rabie 2004). The data were analysed by employing the steps of Tesch's descriptive data analysis. These steps include getting a sense of the whole and writing ideas in the margin; selecting the most interesting interview, determining its underlying mean and jotting down ideas in the margin; clustering similar topics and unique topics; choosing the most descriptive wording for the selected topic; and defining and grouping the topics into categories.

In establishing the trustworthiness of Lincoln and Guba's study (1985), the four criteria of trustworthiness of qualitative data were adhered to, namely credibility, dependability, confirmability and transferability (Holloway and Wheeler 2002; Polit and Beck 2008). To maintain credibility, all interviews from participants were recorded, transcribed and analysed, and this study was done over a period of three years. Moreover, member-checking was performed to ensure the accuracy of transcriptions and interpretations. Dependability was ensured by considering certain changing conditions in the research design, which were brought about by an increasingly refined understanding of both the setting and the topic. This refined understanding of the study and the findings from interviews led to adaptions to the interview and probing questions used in the study. To ensure confirmability (neutrality) an attempt was made to remain objective throughout the data collection process and analyses by guarding against bias and subjectivity, which could have an impact on the description and interpretation of data. To ensure transferability, sufficient and appropriate descriptive information was presented in this study.

Ethical issues were addressed at every stage of the research (Flick 2009). The following ethical measures were taken: obtaining the necessary permission from the Department of Education to conduct the research; informing all participants about the intended study and obtaining their informed consent; protecting participants' identity; ensuring participants' confidentiality; respecting the privacy of participants; and informing participants that they could withdraw from the study at any time (McMillan and Schumacher 2010; Neutens and Rubinson 2010).

\section{FINDINGS AND DISCUSSION}

The private higher education institution in the study had two campuses, one in Gauteng and the other in the North West Province. The management team who participated in the study was based on the Gauteng campus and regularly visited the campus in the North West Province. The institution was accredited in 2000 and offered 15 full-time accredited vocational programmes through contact education. The institution offered as one-year, two-year and threeyear programmes. At the time of the study the institution had 749 registered students, 69 academic staff members and 29 support staff members (Department of Education 2008). 
In the analysis of data the following categories emerged: government's mandate in relation to private higher education; recognition of and value added to private higher education; and the effect of the higher education regulatory framework on the management team and institution.

\section{Government's Mandate in Relation to Private Higher Education}

The following subcategories emerged from participants' responses: recognition of private higher education providers; and the barriers created by the regulatory framework for management functions.

\section{Recognition of Private Higher Education Providers}

Managers had different views on what the government's mandate entailed, and some did not even have clarity on what government's mandate for private higher education was or should be. In general, the feeling of the management team was that the government either did not fulfil its mandate or fulfilled it inadequately. The Chief Executive Officer and Head: Finance were of the opinion that government's mandate was only applicable to the recognition of private higher education institutions, and mainly involved regulation and control functions. It did not include the promotion and development of the private higher education sector. The Chief Executive Officer stated that the government did not have a mandate apart from recognising the institution and regulating programmes to ensure that they were "not weaker 'diluted' deliveries" in comparison to the programmes offered by public universities. Government's mandate was therefore to control institutions to ensure that they delivered high-quality programmes. The view that government's mandate is to regulate private higher education was reiterated by the Association of Private Providers of Education and Development's (APPETD) publication of a summary of a Workshop held by the Department of Higher Education and Training with Private Higher Education Institutions on 27 February 2014: “Government's attitude can be summarised as follows: Government is mandated to regulate the Higher Education, PHEIs are forced to comply" (Association of Private Providers of Education and Development 2014).
The Academic Director was not aware of any government mandate and indicated that private providers had to work hard and actively seek recognition from the government by regularly attending regulatory meetings and sitting on regulatory committees. The Academic Director explained:

We [private providers] got so far because the private education institutions ... were the people who really infiltrated the Department of Education meetings and served on committees and [attended] seminars [so] that they heard about us ... .

The Registrar echoed these views concerning the recognition of an institution:

The mandate is only fulfilled in the sense that the regulatory framework and legislation make provision for equality between public and private institutions. Post-public and private higher education institutions are governed by the same legislation .... .

When the managers were asked about their views of government's mandate, they also mentioned that the regulatory framework for institutional management functions created certain barriers.

\section{Barriers Created by the Regulatory Framework for Management Functions}

Although participants said that increased communication from government to private providers benefited management and led to clearer internal communication in the institution, they also voiced concerns. Managers criticised government's fulfilment of their mandate towards private higher education providers since this mandate generated barriers that hindered managers in carrying out their tasks.

The two main barriers to management functions, according to the views expressed by the managers, were the inconsistency of the government's regulation and control of all the roleplayers in the higher education sector, and the lack of financing for private higher education students. The Head: Student Recruitment indicated that the government did not apply the regulatory function consistently across the higher education sector. He believed that government was not acting against institutions that did not comply with regulations and laws. In addition, the Registrar viewed student funding as a barrier: 
Students in private higher education [institutions] have no access to state student loans or state funding .... . The government doesn't make funding available for students to enter private higher education [institutions]... [A]ccess to private higher education is determined by the wealth of the learner or the student and not by financial support from the government.

This view in term of student funding was highlighted by the Association of Private Providers of Education and Development's (APPETD) publication of a summary of a Workshop held by the Department of Higher Education and Training with Private Higher Education Institutions on 27 February 2014: “DHET currently through their irrational interpretation of the Act excludes students and therefore operates discriminatory against students (Association of Private Providers of Education and Development 2014).

In addition, the findings were supported by the systems theory, because the external regulatory environment was largely influenced by the conditions in which private providers operate. It affected the type and quality of private providers, the accreditation of institutions and their programmes, and student enrolment, which in turn affected the viability of institutions. Similar findings were recorded by the research team of the study The impact of the Higher Education Quality Committee accreditation on private higher education in South Africa (Council on Higher Education 2006a). This study supports the views of the management team regarding clarity on the mandate of government, the intervention by private higher education providers themselves to gain recognition, and communication challenges between the government and private higher education providers. The findings of the HEQC [Higher Education Quality Committee] evaluative study of institutional audits 2006 also support the view that the private higher education providers themselves intervene to gain recognition: “... they believed participation would provide them with possible new insights which would strengthen the institution ..." (Council on Higher Education 2007). Strengthening the institution could contribute to the recognition of the higher education institution sector in general and private higher education institutions in particular.

\section{Recognition of and Value Added to Private Higher Education}

For private higher education providers, the process of gaining recognition as institutions and as a sector was challenging and it impacted on the managerial functions of management. The Registrar was of the opinion that recognition of private higher education institutions and their programmes would only change with time (as the sector grew older), and not necessarily as the result of changes to the regulatory context or the implementation of the regulatory framework. According to him the private higher education sector was not old enough to have established itself like the public education system had done. He thought it would probably take 20 to 25 years before the sector would gain the recognition it sought.

The regulatory context includes conditions that relate to the nature and extent of quality assurance systems and processes, and the quality of teaching and learning at the private higher education institution. The management team's views of the value these conditions added to the recognition of the private higher education sector and higher education sector respectively were grouped in the following two subcategories: value and credibility of private providers; and barriers to maintaining the recognition and value of private providers.

\section{Value and Credibility of Private Providers}

Many of the managers agreed that the regulatory context was valuable and added to the recognition of the private higher education sector by the general public and government, as well as its credibility. The Registrar summarised the increased recognition of the private higher education sector as follows:

It [the regulatory framework] was extremely valuable in the sense that it divided the sector into honest, real higher education institutions ...; the sector as a whole has benefited from it tremendously... . It [the private higher education sector] also ... can be perceived to be equal to a public [higher education] sector in terms of [the] quality [it delivers] that would not have taken place if it were not for a regulatory framework.

Other management members were in agreement with the Registrar's view of the positive influence on the recognition of the private higher education sector. The Head: Student Recruit- 
ment indicated that there was a "more visible appearance" of private providers in South Africa, while the Chief Executive Officer said that "private higher education [institutions] are viewed as a real sector that exists ... [and] students have another option for higher education [and] training apart from the public sector."

The accreditation of private higher education was linked to the quality assurance systems and processes at institutions. The Chief Executive Officer explained: "The most important [aspect] is that this quality assurance has brought with [it] not only quality, but also ... a greater confidence in high-quality providers in the industry." In line with this view the Registrar stated that the enforced quality assurance measures improved the quality of institutions and therefore had "a tremendous positive impact on the institution".

To maintain accreditation, private higher education institutions were required to submit an annual report to the Department of Education, along with supporting documentation to prove the quality and viability of the institution. Such documents included a tax clearance certificate, the surety document, financial statements and other documents that proved the feasibility and quality of the institution.

Other managers had different views on the value of the regulatory context. The Registrar viewed it as a "paper-based value in the sense that the institutions are treated as equals on paper ... . [We] [private higher education institutions] are still perceived to be a money-making enterprise only".

This view that private higher education institutions were mainly focusing on profit was not fully supported by the Association of Private Providers of Education and Development's (APPETD) publication of a summary of a Workshop held by the Department of Higher Education and Training with Private Higher Education Institutions on 27 February 2014.

Another argument that PHEIs are only forprofit is unfounded as there are many NPCs operating in this field (Association of Private Providers of Education and Development 2014).

This view was shared by the Academic Director, who explained that the private higher education sector had not previously been recognised by the Department of Education: "[W] were seen as people who wanted to barge into the world of the public sector ... [T] hey [Depart- ment of Education] were actually against us." Moreover, he believed that no university recognised private higher education institutions, because universities did not believe that private providers were working on the same level as they did, although all accreditation was done by the Council of Higher Education.

The management staff interviewed believed that their institution offered programmes of a high quality and that they constantly strived to improve the quality of their programmes. Their institution also encouraged staff to further their studies and to improve their classroom practice constantly. The Academic Director elaborated on the process to improve the quality of teaching and learning:

... we [management] check everything: we check our exam papers; we check our tests; we check that there is discipline among the students, among the lecturers, ... because we never ever want the public to say that the private sector is of a lower level.

As such the managers held the general view that the implementation of the regulatory context contributed to the validity of private providers. According to the Registrar "people come to realise that the enforced quality assurance measures actually improved the quality of what they do and ... it made a tremendous positive impact on institutions". The result was that the industry was more assured of high-quality service provision in the sector since it could declare its registration with Department of Higher Education. Moreover, private higher education institutions never wanted the public to consider them as operating on a lower level than public higher education institutions.

Although participants valued the impact of the regulatory framework on private providers, the regulatory framework did not focus on the classroom level where programmes were offered. It implied that quality in teaching depended on the institution's own internal processes since the external framework of quality assurance did not explicitly regulate the quality of teaching and learning in classrooms, but merely evaluated particular processes, procedures and policies. Therefore, changes to the current regulatory context, as far as the conditions in relation to quality assurance in classrooms were concerned, were regarded as inevitable. The Registrar was of the opinion that the "powers" needed to realise that their interventions in the reg- 
ulatory framework did not address the core issues in the classroom, such as adequate timetabling, adequate weighting in terms of practical work, the quality of lectures and the variation of teaching delivery. Consequently, he believed, the next round of quality assurance interventions should focus on the quality of teaching and learning the classroom, and not on the operations, policies and procedures of the institution.

Data showed not only that the regulatory framework positively impacted on the recognition of private providers, it also indicated that certain barriers existed to maintaining this recognition.

\section{Barriers to Maintaining the Recognition and Value of Private Providers}

It was clear that participants thought the main barrier faced by the management of the institution and the private higher education sector in general, was to maintain recognition and to counteract the negative impact that illegal higher education role-players had on their status. Some private higher education institutions were not accredited, nor were their programmes registered by the Department of Education. This negatively influenced the image of the private higher education sector in South Africa.

Maintaining the recognition of legal private higher education institutions was perceived as a barrier by private higher institutions, even though institutions met the conditions set out in the regulatory context. The Chief Executive Officer explained: "Private higher education is not yet perceived to be equal to public higher education.” Private providers were still perceived to be a second-best opportunity for students to further their studies.

This viewpoint regarding recognition of private higher education institutions was also supported by the Association of Private Providers of Education and Development's (APPETD) publication of a summary of a Workshop held by the Department of Higher Education and Training with Private Higher Education Institutions on 27 February 2014.

"...the Department believes that the public sector is the core of the education and training system (Department of Higher Education and Training 2013; Association of Private Providers of Education and Development 2014).

In general, the managers viewed programme articulation in practice to be difficult to a point of impossibility. They indicated that the regulatory framework made provision for so-called "seamless articulation", but that it did not work in practice and very little articulation occurred between institutions. The Registrar regarded the regulatory framework as an additional barrier, because it was merely "a paper exercise”. It neither worked between public institutions nor between private and public institutions. Articulation depended on whether the public tertiary education institution recognised students' qualifications awarded by private institutions. The Academic Director explained that articulation between a private and a public higher education institution had to be negotiated with the managers of the different departments at the institutions. Representatives from private institutions had to visit their counterparts at public institutions to provide the necessary information about the content of programmes and how students were assessed at each level of the programme. The Chief Executive Officer indicated that it was much easier to deal with articulation between private institutions than to articulate from the private sector to public universities. He believed that this was very difficult, sometimes "almost impossible". Moreover, the Registrar was of the opinion that articulation between institutions could not be regulated, because paper 37 of the Act stated that entry into any higher education institution was determined by the institution itself.

The findings show the relationships and interactions between institutions and their environment, in this case other public and private higher education institutions, the public and also the Department of Education. Findings recorded by the research team in the studies entitled The impact of the Higher Education Quality Committee accreditation on private higher education in South Africa (Council on Higher Education 2006a) and HEQC (Higher Education Quality Committee) evaluative study of institutional audits 2006 (Council on Higher Education 2007) support the views of the management team regarding value added through the implementation of the regulatory context. Findings concerning the recognition of the private higher education sector, the value added through the quality assurance systems and processes, and the lack of programme articulation in the higher education sector are confirmed. The Higher Education Quality Committee accreditation systems 
have not been able to forge and enhance seamless articulation between programmes and institutions, especially not in relation to the vertical and horizontal articulation of learning programmes among private and public universities (Council on Higher Education 2006a).

The implementation of the regulatory framework also led to certain changes in private higher education institutions.

\section{The Effect of the Higher Education Regulatory Framework on the Management Team and Institution}

The participants indicated that the higher education regulatory framework had brought about certain changes to institutional documentation, quality assurance systems and procedures, and the quality of teaching and learning. The Registrar explained that "management structures necessarily had to adapt to meet the requirements of various Acts and various regulations, which in a sense ... prescribe how ... the higher education institute should [be managed]".

The regulatory framework assisted management in identifying the necessary portfolios in the institution, such as staff responsible for the running of the institution, quality assurance, marketing, finances, the registration of students and the issuing of qualifications according to the rules and regulations of the regulatory framework. The Academic Director added that they worked according to the regulatory framework, which gave them the necessary background to structure their programmes well. Moreover, the Chief Executive Officer indicated that the guidelines in the framework assisted management "in not taking too ... wild and quick decisions ..."

The main barrier encountered by the management team was at the strategic level. According to the Registrar, the Higher Education Act did not acknowledge that private higher education institutions were businesses and not only institutions; although institutions had to meet the requirements of all other education Acts, they were also businesses that needed to be profitable. Being profitable was one of the prerequisites of maintaining registration with the Council for Higher Education. The Chief Executive Officer added that this then resulted in making it extremely difficult to acquire capital through growth, through investment or by buying shares within the regulatory framework. On the other hand, some decisions based on the impact of the regulatory framework were viewed as beneficial for management functions.

Findings recorded by the research team of the study The impact of the Higher Education Quality Committee accreditation on private higher education in South Africa (Council on Higher Education 2006a) and the HEQC (Higher Education Quality Committee) evaluative study of institutional audits 2006 (Council on Higher Education 2007) support the views of the management team on the impact of regulatory framework. These included their views on the development of the necessary management structures and functions, updating and strengthening institutional policies, changing of departmental processes and procedures, and business decisions that add to the recognition of the institution. This is supported by the Association of Private Providers of Education and Development's (APPETD) publication of a summary of a Workshop held by the Department of Higher Education and Training with Private Higher Education Institutions on 27 February 2014.

"PHEIs are unanimous in their acceptance of and support for a quality assurance process. Each PHEI invest millions into a business project, therefore the PHEIs will do their utmost to ensure financial and operational success and will of necessity to be compliant with regulatory and quality assurance requirements as long as those requirements are rational and reasonable." (Department of Higher Education and Training 2013; Association of Private Providers of Education and Development 2014).

The systems theory supports the findings that show that a private higher education institution does not work in isolation. The findings also show how the regulatory framework has influenced the structures of the institution. The regulatory framework impacted the decisions made and the policies and procedures formulated; and had an overall impact on the running of the institution. In turn, these changes impacted on the quality of the institution and should lead to recognition of the institution and its programmes. The institution also had to identify with national goals in South Africa and act as an agent of the state (Council on Higher Education 2007: 29-30). Management accommodated all these changes and provided for additional attention to quality assurance policies and proce- 
455

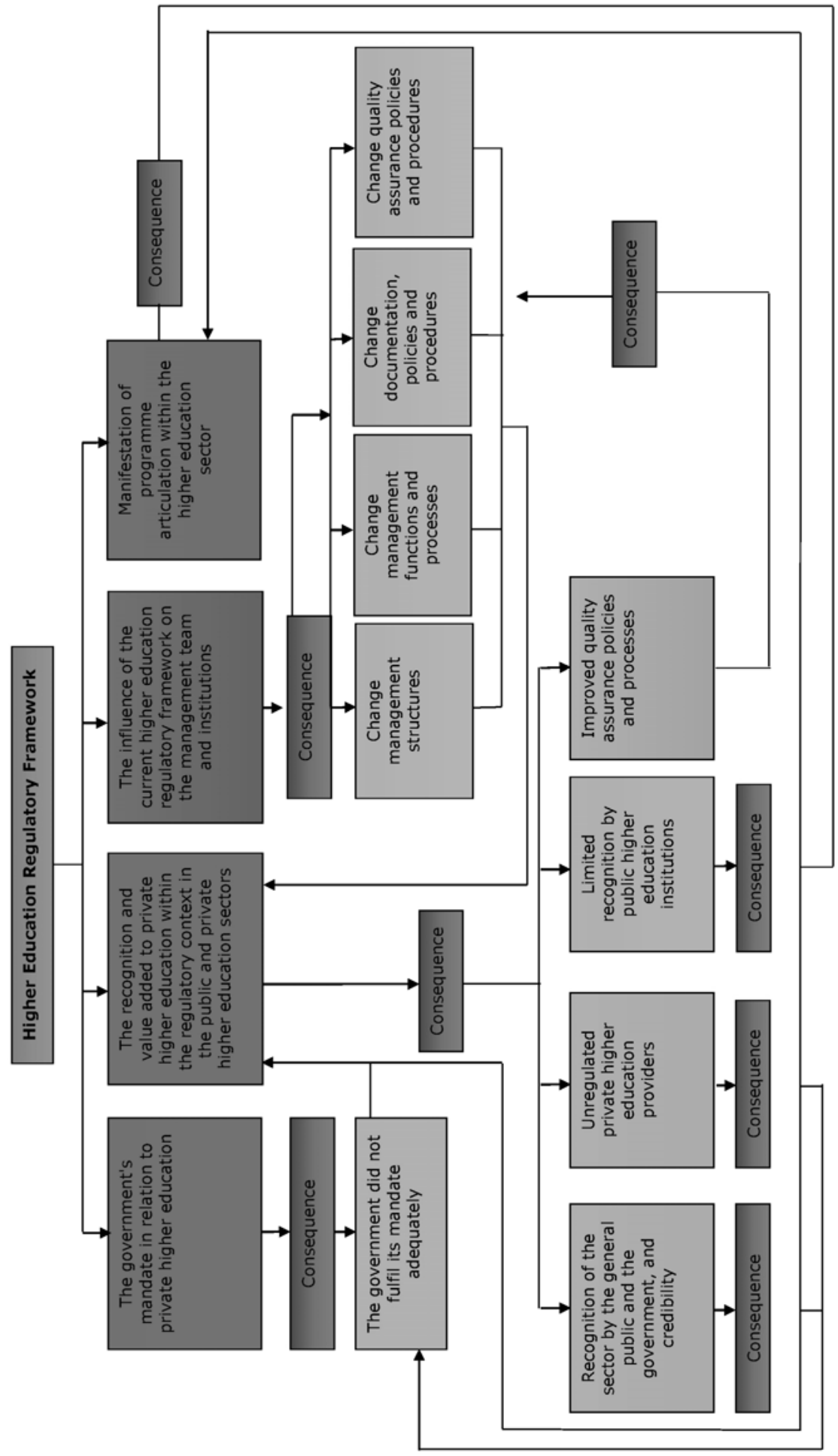


dures. They anticipated that adhering to all these changes would enhance the recognition given to the private higher education institution and its programmes.

The findings of the study are depicted in Figure 1, which shows the way in which the managers experienced the regulatory environment in South Africa. Figure 1 also depicts the consequences of legislation and the associated regulatory framework for the management team and the private higher education sector. Government's higher education mandate was instrumental in the impact on the regulatory framework (first feature). With government not adequately fulfilling its mandate in terms of private higher education, the level of recognition of private higher education was prejudiced. This led to the second feature, which set out to identify the factors that either added or detracted value and recognition of the private and public higher education sectors within the regulatory context, resulting in four factors and their consequences:

- The recognition and credibility of the private higher education sector by the general public and government.

Consequence: Value and recognition was added to the private higher education sector and higher education sector.

- Unregulated private higher education providers.

Consequence: Providers did not add value to or recognise the private higher education sector and higher education sector, but had a rather negative impact on the sector.

- Limited recognition by public higher education institutions.

Consequence: Limited programme articulation within the higher education sector.

- Improved quality assurance policies and procedures.

Consequence: Changes to the management team's functions, processes and procedures. This could be categorised into four manifestations of change, namely: management structure; management function and processes; documentation, policies and procedures; and quality assurance policies and procedures.

These manifestations of change were interrelated and could not easily be separated from one another. The third feature also had a consequence: the influence of the higher education regulatory framework on the management team and institution. Thus, change to the manage- ment structures resulted in changes in management functions and procedures, ensuing in changes in institutional documentation, policies and procedures and ultimately changes in quality assurance policies and procedures. These changes also added value and recognition to the public and private higher education sectors (feature two).

\section{CONCLUSION}

Government, while fulfilling its mandate to regulate and recognise private higher education institutions, did not develop the private higher education sector. The regulating and control function of the government notwithstanding, managers thought legislation had had a valuable impact on private higher education institutions, as it added to the recognition and credibility of the sector. The perceived inequality of public and private higher education providers, the articulation of programmes and the perception that private higher education is a secondbest choice for students were raised as concerns.

Government documents are silent on the forprofit and business-oriented approach of a proprietary limited company in higher education. This posed a barrier to entrepreneurial endeavours and management's opportunities to acquire capital, because the regulatory framework did not make it clear that higher education private institutions were businesses that had to meet the requirements of appropriate Acts while also turning a profit. These conclusions call for ongoing investigation into the regulation of higher education in South Africa in general. The study of management perceptions of the regulation of private higher education would benefit from an analysis of all higher education sectors from a regulatory perspective.

\section{REFERENCES}

Adam K 2003. Women Empowerment and Leadership in Education: A Key Factor for Emiratisation in the United Arab Emirates. Doctoral Thesis, Unpublished. Pretoria: University of South Africa.

Association of Private Providers of Education Training and Development 2014. DHET Workshop with PHEIs -27 February 2014. From <http://www. google.co.za/url? $\mathrm{sa}=$ tandrct $=$ jandq $=$ andesrc $=$ sand source $=$ webandcd $=5$ andved $=0$ CEAQFjA Eandurl $=$ http\%3A\% 2F\%2 Fwww.appetd.org.za\% 2Fmember\%2 Findex. php\%2 Fdownloads\%2 Fcategory\% 2F25-dhet-workshop-with-pheis\%3Fdownload\% 
3D31\%3 Areport-on-dhet-workshop-with-privatehigher-education-institutionsandei=TRg9U_ ug B6ar7 Aa5iIHQCgandu sg=AFQjCNE0ye KuXyuwKekXeq RTYaSyGDMrTwandsig2 $=\mathrm{KKnVneL}$ RFv9MQ0t-76umdA> (Retrieved on 3 April 2014).

Asimiran SB 2009. Governance of Public Universities in Malaysia. Doctoral Thesis, Unpublished. Malaysia: University of Malaya.

Badat S 2007. Higher Education Change in Post-1994 South Africa: The Dynamics of Change and Questions and Issues in Search of Sociological Inquiry. African Studies Programme. Princeton, New Jersey: Princeton University.

Baine EMM 2010. Privatisation of higher education in Uganda and the global gender justice ideal: Uneasy bedfellows? Educational Review, 62(3): 315-328.

Bush $T$ 2011. Theories of Educational Leadership and Management. $4^{\text {th }}$ Edition, Sage Publications: London.

Cloete N 2014. A new look at demographic transformation: Comments on Govinder et al. 2013. South African Journal of Science, 110(1/2): 25-29.

Cohen L, Marion L, Morrison K 2007. Research Methods in Education. 6 6 ${ }^{\text {th }}$ Edition. London: Routledge.

Council on Higher Education 2003. How to Identify a 'Fly-by-night' Institution? Pretoria: Council on Higher Education.

Council on Higher Education 2004. Criteria for Programme Accreditation, Pretoria: Council on Higher Education.

Council on Higher Education 2006a. The Impact of the Higher Education Quality Committee Accreditation on Private Higher Education in South Africa. Second Draft. Pretoria: Council on Higher Education.

Council on Higher Education 2006b. External (and Internal) Tensions? Conceptualising Public Accountability in South Africa Higher Education, $\mathrm{CHE}$ HEIAAF, 2: 17-21. Pretoria: Council on Higher Education.

Council on Higher Education 2007. HEQC Institutional Audit Manual 2007. Pretoria: Council on Higher Education.

Creswell JW 2007. Qualitative Inquiry and Research Design Choosing among Five Approaches. $2^{\text {nd }}$ Edition. Thousand Oaks, CA: Sage Publications.

Daigneau WA 2005. Planning, designing and managing higher education institutions. PEB Exchange, Journal of the OECD Programme on Educational Building, 3(56): 13-15.

Department of Education 1997a. Education White Paper 3: A Programme for the Transformation of Higher Education. Government Gazette No. 18207. Pretoria: Department of Education.

Department of Education 1997b. Higher Education Act No. 101 of 1997. Government Gazette No. 18515. Pretoria: Government Printers.

Department of Education 2001. National Higher Education Plan. Government Gazette No. 22138. Pretoria: Government Printers.

Department of Education 2002. Higher Education Act, 1997: Regulations for the Registration of Private Higher Education Institutions. Government Gazette No. 24143. Pretoria: Government Printers.

Department of Education 2004. What Students and Parents Need to Know about Enrolment at Private
Education Institutions. Pretoria: Government Printers.

Department of Education 2008. Register of Private Higher Education Institutions 17 October 2008. Pretoria: Department of Education.

Department of Education and Skills 2011. National Strategy for Higher Education to 2030 - Report for the Strategy Group. Higher Education Strategy Group. Dublin: Government Publications Sales Office.

Department of Higher Education and Training 2013. White Paper for Post-School Education and Training: Building and Expanded, Effective and Integrated Post School System. Pretoria: Department Higher Education and Traning.

Department of Labour 1997. Basic Conditions of Employment Act No. 75 of 1997. Government Gazette 18491. Pretoria: Government Printers.

Department of Trade and Industry 1973. Companies Act 61 of 1973. Pretoria: Government Printers.

Dubash N, Morgan B 2011. Understanding the Rise of the Regulatory State in the Global South. Working Paper No 32. Jerusalem Papers in Regulation and Governance. From <http://regulation.huji.ac.il/papers/jp32.pdf $>$ (Retrieved on 19 November 2012).

Flick U 2009. An Introduction to Qualitative Research. London: Sage Publications.

Giles D 2007. Humanising the researcher: The influence of phenomenological research on a teacher educator. International Journal of Pedagogies and Learning, 3(1): 6.

Gravett S, Geyser H 2004. Teaching and Learning in Higher Education. Pretoria: Van Schaik.

Holloway I, Wheeler S 2002. Qualitative Research in Nursing. $2^{\text {nd }}$ Edition. London: Wiley-Blackwell.

King R 2006. Analysing the Higher Education Regulatory State. Discussion Paper 38', November. London: Centre for Analysis of Risk and Regulation at the London School of Economics and Political Science. From <http://eprints.lse.ac.uk/36119/1/ Disspaper38.pdf $>$ (Retrieved on 20 November 2012).

Kruger S 2010. Art and Science of Teaching: National Qualifications Framework Level 4. Cape Town: Juta and Company Ltd.

Laszlo A, Krippner S 1998. Systems theories: Their origins, foundations, and development. In: JS Jordan (Ed.): Systems Theories and a Priori Aspects of Perception. Amsterdam: Elsevier, pp. 47-74.

Lincoln YS, Guba EG 1985. Naturalistic Inquiry. London: Sage.

Livesey C 2006. Sociological Research Methods. From $<$ http://www.sociology.org.uk/revgrm5.pdf > (Retrieved on 22 November 2012).

Nachef T, Bin Jantan M, Boularas A 2014. Fuzzy modelling for Qatar knowledge-based economy and its characters. Modern Economy, 5: 224-238.

MacGregor K 2008. South Africa: Private Higher Education Stabilises. From <http://www. university worldnews.com/publication/archives. php?mode=a rchiveandp_id=Africa_Editionandissueno= 4andformat $=\bar{h}$ tml $>$ (Retrieved on December 4, 2012).

McMillan JH, Schumacher S 2010. Research in Education: Evidence-based Inquiry. $7^{\text {th }}$ Edition. Boston, New Jersey, USA: Pearson Education.

Moran M 2002. Review paper: Understanding the regulatory state. British Journal of Political Science, 32: 391-413. 
Newton RR 2002. For-profit and traditional institutions: A comparison. International Higher Education, 27: 13-15.

Neutens, J, Robinson L 2010. Research Techniques for the Health Sciences. New York: Pearson Education, Inc.

Nieuwenhuis J 2010. Introducing qualitative research. In: K Maree (Ed.): First Steps in Research. Pretoria: Van Schaik Publishers, pp. 46-68.

Pandor N 2004. We Cannot Stand by and Watch Institutions Collapse. From <http://chet.org.za/webfm send/393> (Retrieved on 7 April 2011).

Polit DF, Beck CT 2008. Nursing Research: Generating and Assessing Evidence for Nursing Practice. $8^{\text {th }}$ Edition, Philadelphia: Lippincott Williams and Wilkins.

Smit PJ, Cronjé G, de J, Brevis T, Vrba MJ 2007. Management Principles. A Contemporary Edition for Africa. $4^{\text {th }}$ Edition, Cape Town: Juta and Co.

Stacey RD, Griffin D, Shaw P 2000. Complexity and Management: Fad or Radical Challenge to Systems Thinking? London: Routledge.

Subotzky G 2003. Private higher education and training. In: Human Resources Development Review
2003- Education, Employment and Skills in South Africa. Pretoria: Human Sciences Research Council Press.

Van der Bank CN, Basson RL 2014. Quality assurance in a University of Technology in context of three elements: Quality, standards and relevance. Journal of Educational and Social Research, 4(1): 107117.

Vidovich L, Currie J 2011. Governance and trust in higher education. Studies in Higher Education, 36(1): 43-56.

Visagie RG 2002. Stories of Merger and Acquisition Change: A Team-based Approach in the Promotion of Mental Health. Doctoral Thesis, Unpublished. Johannesburg: Rand Afrikaans University.

Wang L 2010. Higher education governance and university autonomy in China. Globalisation, Societies and Education, 8(4): 477-495.

Warren CAB 2002. Qualitative interviewing. In: JF Gubrium, JA Holstein (Eds.): Handbook of Interview Research: Context and Method. Thousand Oaks, California: Sage Publications, pp. 83-102.

Wholey JS, Hatry HP, Newcomer KE 2004. Handbook of Practical Program Evaluation. San Francisco: Jossey Bass. 